\title{
Cultural Characterization of Alternaria spp. Associated with Alternaria Blotch of Apple
}

\author{
Praneet Chauhan $^{1 *}$, A.K. Gupta ${ }^{1}$, J.N. Sharma ${ }^{1}$, Monica Sharma ${ }^{1}$, \\ J.S. Chandel ${ }^{2}$ and R.K. Gupta ${ }^{3}$ \\ ${ }^{1}$ Department of Plant Pathology, ${ }^{2}$ Department of Fruit Science, ${ }^{3}$ Department of Basic \\ Sciences, Dr. Yashwant Singh Parmar University of Horticulture and Forestry, \\ Nauni, Solan, Himachal Pradesh, India
}

*Corresponding author

A B S T R A C T

\begin{tabular}{|l|}
\hline Ke y w or d s \\
Apple, Blotch, \\
Cultural, \\
Sporulation \\
\hline Article Info \\
\hline $\begin{array}{l}\text { Accepted: } \\
\text { 12 July } 2018 \\
\text { Available Online: } \\
\text { 10 August } 2018\end{array}$ \\
\hline
\end{tabular}

Alternaria blotch causes severe foliar defoliation to apple trees in Himachal Pradesh. Sixteen isolates of Alternaria spp. were collected from different locations and characterized for cultural variations. Alternaria alternata f. sp. mali varied in their cultural behavior ranging from velvety to cottony, mostly appressed, with regular to irregular margins. Colour of colonies ranged between light to dark olivaceous. The nutritional studies were undertaken to know the best medium required for the growth and sporulation of the test pathogen. The study revealed that out of six different solid media tested, potato dextrose agar (PDA), malt extract agar and Asthana and Hawker's agar medium proved best for mycelial growth and sporulation of the test pathogen, respectively.

\section{Introduction}

Apple (Malus $\times$ domestica Borkh.) belongs to family Rosaceae and it is the most important fruit crop grown extensively in temperate regions of the world. The area under apple cultivation has increased manifold during the last few decades but the production has not increased proportionally and the productivity is quite low in comparison to advanced apple growing countries of the world. Like other horticultural crops apple is also attacked by several pathogens which impair the quality and quantity of the fruit. Huge losses of the crop are incurred mostly by fungal diseases. The major fungal diseases include scab, Alternaria leaf blotch, powdery mildew, collar rot, root rot, sooty blotch, fly speck, etc.

Among these, Alternaria blotch caused by Alternaria mali, prevalent in all apple growing areas of the world is an economically important apple disease. Alternaria mali was first described in 1924 in the United States by Roberts and become a problem in the southeastern United States. The disease 
assumed alarming threat to the crop owing to premature defoliation in North Carolina and has potential of becoming threat especially in those apple and loquat producing regions where susceptible cultivars/strains of Delicious are grown (Filajdic and Sutton, 1991). A. mali has attained the status of economically important disease in many Asian countries including Japan and India (Jones and Aldwinckle, 1990). The fungus obtains food and energy from the substrate upon which they grow in nature, in order to culture the fungus in the laboratory, there is no universal substrate or artificial medium upon which the test pathogen can grow and reproduce.

Therefore studies were conducted in different suitable media to identify surface medium for the growth and sporulation of pathogen involved in Alternaria blotch of apple.

\section{Materials and Methods}

The experiment was conducted in the Fruit Pathology Laboratory, Dr. YS Parmar University of Horticulture \& Forestry, Nauni, Solan (H.P) during the year 2015-16. To find out the suitable medium for the growth and sporulation of the Alternaria spp. six solid media viz., potato dextrose Agar, Asthana and Hawker's Agar, Czapek's dox Agar, malt extract agar, glucose asparagine agar and Dimmick's agar were taken for in vitro studies.

Inoculated plates were incubated at $25 \pm 1^{0} \mathrm{C}$ and observations on mycelial growth (radial) and sporulation were recorded on $2^{\text {nd }}, 4^{\text {th }}, 6^{\text {th }}$ and $8^{\text {th }}$ day after incubation. Best solid medium was used for further studies. Growth on different solid media was determined by measuring the colony diameter along with the two diagonals passing though the centre of colony by excluding initial diameter $(5 \mathrm{~mm})$ of bit and sporulation was recorded by using haemocytometer.

\section{Results and Discussion}

Nutrition plays an important role in growth and sporulation of the fungus. In order to determine basal medium for mycelial growth and sporulation of Alternaria spp. six solid media were tested in vitro. The mycelial growth and sporulation of the test pathogen on nine different solid media was studied as described in the material and methods and results are presented in tables 1,2 and 3. The data presented in Table 1 indicated that Alternaria sp. can grow well on different media. All the isolates tested depicted variation in the growth rate (growth/day) and sporulation (spores/ml) (Table 1 and 2). Isolate 1with mean growth rate of $66.92 \mathrm{~mm}$ followed by Isolate 2,7 and 3 with mean growth rate of $64.13,61.15$ and $60.17 \mathrm{~mm}$, respectively. Least growth rate of $40.08 \mathrm{~mm}$ was recorded in Isolate 6 on potato dextrose agar medium. However, maximum growth of the pathogen after 8 days was observed on potato dextrose agar medium followed by malt extract agar and minimum growth was observed on Czapek's dox agar medium. In case of Asthana and Hawker's medium, maximum mean growth rate $(51.02 \mathrm{~mm})$ was recorded in Isolate 5 followed by Isolate 6 and 11 with mean growth rate of 48.10 and $47.61 \mathrm{~mm}$ which were statistically at par with each other. Least growth rate of $35.06 \mathrm{~mm}$ was recorded in Isolate 8 in Asthana and Hawker's medium.

Maximum mean growth rate of $51.03 \mathrm{~mm}$ followed by Isolate 5 and Isolate 3 with mean growth rate of 49.83 and $49.27 \mathrm{~mm}$ whereas minimum mean growth rate of $35.45 \mathrm{~mm}$ was recorded on Isolate 8 in case of Czapek's dox agar medium. In malt extract medium, maximum mean growth rate of $51.09 \mathrm{~mm}$ was observed in Isolate 10 followed by Isolate 7 , Isolate 15 and Isolate16 with mean growth rate of 50.91, 50.30 and $49.93 \mathrm{~mm}$, respectively which were statistically at par 
with each other. Least growth rate of 34.24 $\mathrm{mm}$ was recorded in Isolate 8 . In case of glucose asparagine medium, highest mean growth rate $(47.33 \mathrm{~mm})$ was recorded on Isolate 3 followed by Isolate 12, Isolate 15 and Isolate 2 with mean growth rate of 47.19 , 46.40 and $45.21 \mathrm{~mm}$, respectively. Whereas in case of Dimmick's agar maximum mean growth rate of $46.71 \mathrm{~mm}$ was observed in Isolate 9 followed by Isolate 16 and Isolate 15 with mean growth rate of 46.65 and $45.87 \mathrm{~mm}$. Least growth rate of $32.90 \mathrm{~mm}$ was recorded in Isolate 8.

The sporulation of $20.20 \times 10^{3}$ spores/ml was observed in Isolate 1 followed by Isolate 2, 7 and 3 with sporulation of $20.00 \times 10^{3}$ spores $/ \mathrm{ml}$, $18.50 \times 10^{3}$ spores $/ \mathrm{ml}$ and $18.00 \times 10^{3}$ spores $/ \mathrm{ml}$, respectively. Least sporulation $10.00 \times 10^{3}$ spores/ml was recorded in Isolate 6, 11 and 16 on potato dextrose agar medium. However, maximun sporulation of the pathogen after 8 days was observed on potato dextrose agar medium followed by malt extract agar and minimum sporulation was observed on Czapek's dox agar medium.

In case of Asthana and Hawker's medium, maximum sporulation $\left(3.50 \times 10^{3}\right.$ spores $\left./ \mathrm{ml}\right)$ was recorded in Isolate 5 followed by Isolate 4 and 1 with sporulation of $3.25 \times 10^{3}$ spores $/ \mathrm{ml}$ and $3.00 \times 10^{3}$ spores $/ \mathrm{ml}$, respectively. Least sporulation of $1.50 \times 10^{3}$ spores $/ \mathrm{ml}$ was recorded in Isolate 11, 14 and 15 in Asthana and Hawker's medium.

Maximum sporulation of $4.80 \times 10^{3}$ spores $/ \mathrm{ml}$ was observed in Isolate 2 followed by Isolate 1 and Isolate 13 with sporulation of $4.50 \times 10^{3}$ spores $/ \mathrm{ml}$ and $4.50 \times 10^{3}$ spores $/ \mathrm{ml}$ whereas minimum sporulation of $2.50 \times 10^{3}$ spores $/ \mathrm{ml}$ was recorded on Isolate 6,15 and 16 in case of Czapek's dox agar medium. In malt extract medium, maximum sporulation of $12.00 \times 10^{3}$ spores $/ \mathrm{ml}$ was observed in Isolate 2 and Isolate 4 followed by Isolate 3 and Isolatel with sporulation of $11.50 \times 10^{3}$ spores $/ \mathrm{ml}$ and $11.00 \times 10^{3}$ spores $/ \mathrm{ml}$, respectively. Least sporulation of $8.00 \times 10^{3}$ spores $/ \mathrm{ml}$ was recorded in Isolate 11 . In case of glucose asparagine agar medium, highest sporulation $\left(14.00 \times 10^{3}\right.$ spores $\left./ \mathrm{ml}\right)$ was recorded on Isolate 1 and Isolate 7 followed by Isolate 6 , Isolate 11 and Isolate 15 with sporulation of $13.50 \times 10^{3}$ spores $/ \mathrm{ml}, 13.45 \times 10^{3}$ spores $/ \mathrm{ml}$ and $13.40 \times 10^{3}$, respectively. Whereas in case of Dimmick's agar maximum sporulation of $9.50 \times 10^{3}$ was observed in Isolate 1 followed by Isolate 8 and Isolate 10 with sporulation of $8.65 \times 10^{3}$ spores $/ \mathrm{ml}$ and $8.50 \times 10^{3}$ spores $/ \mathrm{ml}$. Least sporulation of $6.90 \times 10^{3}$ spores $/ \mathrm{ml}$ was recorded in Isolate 4.

Isolates of Alternaria spp. differed with respect to their cultural characteristics. The characters viz. type and color of colony, growth rate of fungus and pigmentation were recorded.

The Alternaria spp. isolates grown on PDA showed variation in their colony characteristics (Table 3). Colony colour varied from light to dark olivaceous with greenish or brownish tinge. Mostly the colonies had velvety or cottony mycelial growth with regular to irregular margin (Plate 1). Colonies developed were either cottony or velvety with slight variations. The velvety growth was observed in ten isolates viz. I-2, I-3, I-6, I-7, I9, I-10, I-11, I-12, I-13 and I-15 and cottony type of growth in six isolates viz. I-1, I-4, I-5, I-8, I-14, I-16.

Among the velvety type of colonies variations recorded were as follows: Appressed growth was observed in I-1, I-3, I-4, I-5, I-6, I-7, I-9, I-10, I-11, I-12, I-13, I-15. I-2 though velvety had cottony central growth. Among the cottony type of colonies furrows developed in I-1, appressed centre was recorded in I-5 and sub-aerial mycelial growth in I-16. The colony of I-4 was with slightly appressed margins. 
Table.1 Effect of different media on the radial growth of Alternaria spp. collected from apple and other hosts

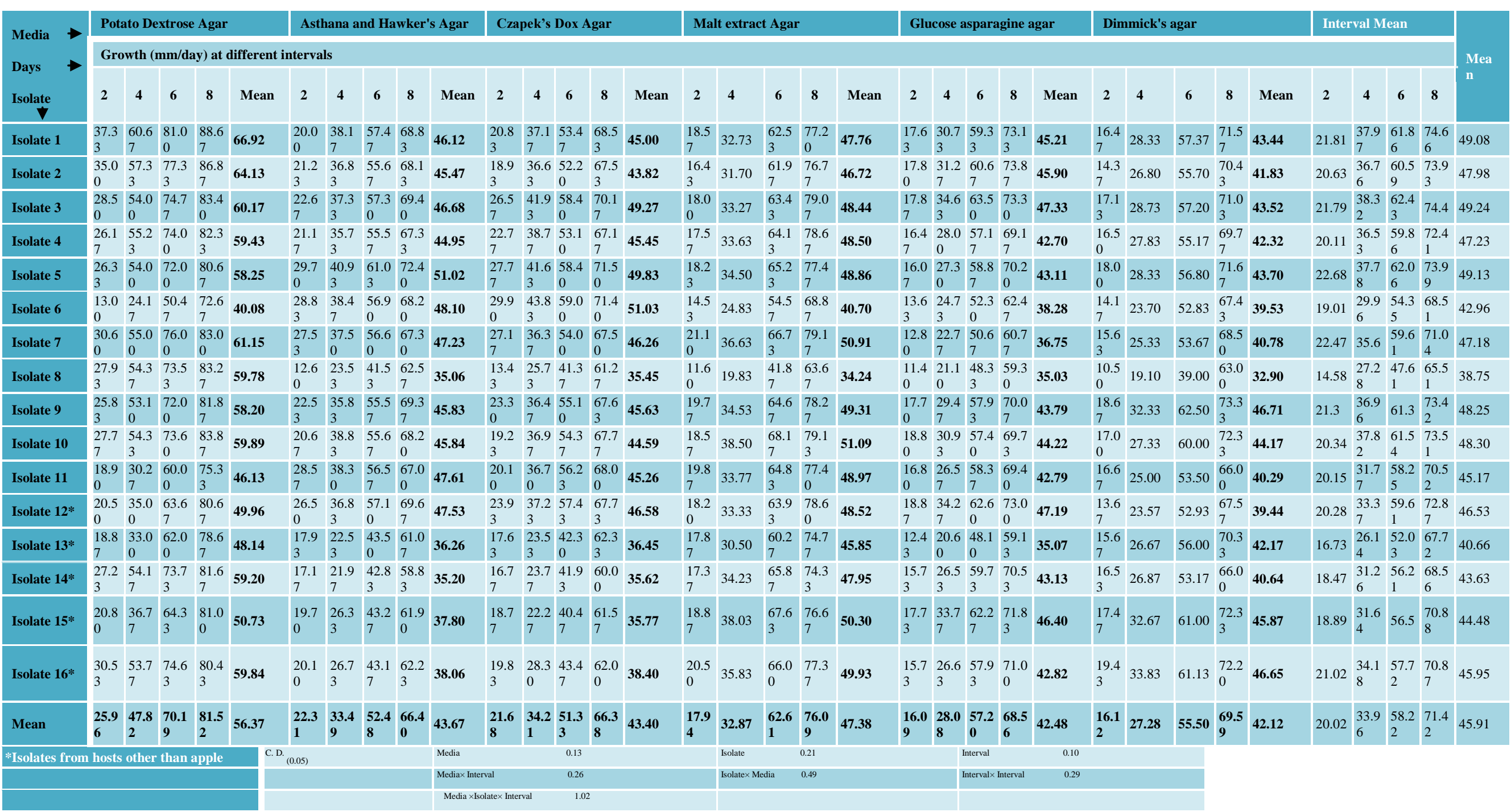


Table.3 Cultural variability of Alternaria spp. collected from apple and other hosts

\begin{tabular}{|c|c|c|c|c|}
\hline \multirow[t]{2}{*}{ Isolate } & \multicolumn{4}{|c|}{ Colony } \\
\hline & Type & Colour & Margin & Colour on the underside of Petri-plate \\
\hline Isolate 1 & $\begin{array}{l}\text { Cottony, slightly furrowed } \\
\text { with appressed centre }\end{array}$ & $\begin{array}{l}\text { Dark olivaceous, with dark } \\
\text { centre }\end{array}$ & $\begin{array}{l}\text { Regular, cottony brownish } \\
\text { margin with whitish rim }\end{array}$ & Smoky grey to dark grey \\
\hline Isolate 2 & $\begin{array}{l}\text { Velvety, with cottony central } \\
\text { growth }\end{array}$ & Olivaceous green & $\begin{array}{l}\text { Slightly irregular, olivaceous } \\
\text { green }\end{array}$ & Dark grey with light grey margin \\
\hline Isolate 3 & Velvety, appressed & Light olivaceous green & $\begin{array}{l}\text { Regular, light brownish } \\
\text { margin with white rim }\end{array}$ & Smoky grey \\
\hline Isolate 4 & $\begin{array}{l}\text { Cottony, with slighty } \\
\text { appressed margins }\end{array}$ & $\begin{array}{l}\text { Olivaceous green with } \\
\text { grayish surface }\end{array}$ & $\begin{array}{l}\text { Regular, brownish with } \\
\text { white rim }\end{array}$ & Grey with light grey margin \\
\hline Isolate 5 & Cottony, appressed centre & Light olivaceous green & $\begin{array}{l}\text { Regular, cottony with white } \\
\text { rim }\end{array}$ & Bluish brown with light grey margin \\
\hline Isolate 6 & $\begin{array}{l}\text { Velvety, slightly furrowed } \\
\text { with appressed centre }\end{array}$ & $\begin{array}{l}\text { Olivaceous with brownish } \\
\text { centre and grayish surface }\end{array}$ & $\begin{array}{l}\text { Irregular, appressed, } \\
\text { olivaceous green }\end{array}$ & Dark grey with light grey margin \\
\hline Isolate 7 & Velvety, Appressed & Olivaceous & $\begin{array}{l}\text { Irregular, appressed, } \\
\text { Olivaceous with white rim }\end{array}$ & Light grey with brown centre \\
\hline Isolate 8 & Cottony, sub-aerial & $\begin{array}{l}\text { Dark green with greyish } \\
\text { surface }\end{array}$ & Regular, dirty white margin & Bluish brown with light grey margin \\
\hline Isolate 9 & Velvety, appressed & Olivaceous green & $\begin{array}{l}\text { Slightly irregular, light green } \\
\text { with grayish rim }\end{array}$ & Light grey with brown centre \\
\hline Isolate 10 & Velvety, appressed & Olivaceous & $\begin{array}{l}\text { Slightly irregular, brownish } \\
\text { with dirty white rim }\end{array}$ & Brown with light grey margin \\
\hline Isolate 11 & Velvety, appressed & Dark olivaceous green & $\begin{array}{l}\text { Irregular, light olivaceous } \\
\text { with grayish rim }\end{array}$ & Smoky grey \\
\hline Isolate $12 *$ & Velvety, appressed & Dark olivaceous green & $\begin{array}{l}\text { Slightly irregular, light } \\
\text { olivaceous with grayish rim }\end{array}$ & $\begin{array}{l}\text { Light brown with light grey margin and } \\
\text { dark brown centre }\end{array}$ \\
\hline Isolate $13 *$ & Velvety, appressed & Olivaceous green & $\begin{array}{l}\text { Slightly irregular, light green } \\
\text { with grayish rim }\end{array}$ & Light grey with dark grey centre \\
\hline Isolate $14 *$ & Cottony, slightly furrowed & Olivaceous & $\begin{array}{l}\text { Regular, cottony olivaceous } \\
\text { with greyish rim }\end{array}$ & $\begin{array}{l}\text { Greyish with light grey margin and } \\
\text { brown centre }\end{array}$ \\
\hline Isolate $15^{*}$ & Velvety, appressed & Olivaceous green & $\begin{array}{l}\text { Regular, appressed, } \\
\text { olivaceous green }\end{array}$ & Smoky grey \\
\hline Isolate $16 *$ & Cottony, sub-aerial & Greenish with grayish surface & $\begin{array}{l}\text { Regular, appressed green } \\
\text { with white rim }\end{array}$ & Light grey with dark grey centre \\
\hline
\end{tabular}

*Isolates from hosts other than apple 
Table. 2 Effect of different media on the sporulation of Alternaria spp. collected from apple and other hosts

\begin{tabular}{|c|c|c|c|c|c|c|c|}
\hline $\begin{array}{l}\text { Media } \longrightarrow \\
\text { Isolate }\end{array}$ & $\begin{array}{c}\text { Potato } \\
\text { Dextrose } \\
\text { Agar }\end{array}$ & $\begin{array}{l}\text { Asthana } \\
\text { and } \\
\text { Hawker's }\end{array}$ & $\begin{array}{l}\text { Czapek's } \\
\text { Dox Agar }\end{array}$ & $\begin{array}{c}\text { Malt } \\
\text { extract } \\
\text { Agar }\end{array}$ & $\begin{array}{c}\text { Glucose } \\
\text { asparagine } \\
\text { agar }\end{array}$ & $\begin{array}{c}\text { Dimmick's } \\
\text { agar }\end{array}$ & Mean \\
\hline$\downarrow$ & $\begin{array}{l}\text { Sporulation } \\
\text { (Spores/ml) }\end{array}$ & $\begin{array}{l}\text { Sporulation } \\
\text { (Spores/ml) }\end{array}$ & $\begin{array}{l}\text { Sporulation } \\
\text { (Spores/ml) }\end{array}$ & $\begin{array}{c}\text { Sporulation } \\
\text { (Spores/ml) }\end{array}$ & $\begin{array}{l}\text { Sporulation } \\
\text { (Spores/ml) }\end{array}$ & $\begin{array}{l}\text { Sporulation } \\
\text { (Spores/ml) }\end{array}$ & \\
\hline Isolate 1 & $20.20 \times 10^{3}$ & $3.00 \times 10^{3}$ & $4.50 \times 10^{3}$ & $11.00 \times 10^{3}$ & $14.00 \times 10^{3}$ & $9.50 \times 10^{3}$ & $10.33 \times 10^{3}$ \\
\hline Isolate 2 & $20.00 \times 10^{3}$ & $2.00 \times 10^{3}$ & $4.80 \times 10^{3}$ & $12.00 \times 10^{3}$ & $13.00 \times 10^{3}$ & $8.00 \times 10^{3}$ & $10.00 \times 10^{3}$ \\
\hline Isolate 3 & $18.00 \times 10^{3}$ & $2.50 \times 10^{3}$ & $3.00 \times 10^{3}$ & $11.50 \times 10^{3}$ & $12.00 \times 10^{3}$ & $8.00 \times 10^{3}$ & $9.25 \times 10^{3}$ \\
\hline Isolate 4 & $17.50 \times 10^{3}$ & $3.25 \times 10^{3}$ & $3.50 \times 10^{3}$ & $12.00 \times 10^{3}$ & $11.00 \times 10^{3}$ & $6.90 \times 10^{3}$ & $9.50 \times 10^{3}$ \\
\hline Isolate 5 & $17.00 \times 10^{3}$ & $3.50 \times 10^{3}$ & $4.00 \times 10^{3}$ & $11.00 \times 10^{3}$ & $12.00 \times 10^{3}$ & $7.50 \times 10^{3}$ & $9.17 \times 10^{3}$ \\
\hline Isolate 6 & $10.00 \times 10^{3}$ & $2.20 \times 10^{3}$ & $2.50 \times 10^{3}$ & $10.50 \times 10^{3}$ & $13.50 \times 10^{3}$ & $7.50 \times 10^{3}$ & $7.70 \times 10^{3}$ \\
\hline Isolate 7 & $18.50 \times 10^{3}$ & $2.00 \times 10^{3}$ & $3.50 \times 10^{3}$ & $10.00 \times 10^{3}$ & $14.00 \times 10^{3}$ & $8.20 \times 10^{3}$ & $9.28 \times 10^{3}$ \\
\hline Isolate 8 & $17.00 \times 10^{3}$ & $2.20 \times 10^{3}$ & $3.70 \times 10^{3}$ & $9.50 \times 10^{3}$ & $12.00 \times 10^{3}$ & $8.65 \times 10^{3}$ & $8.82 \times 10^{3}$ \\
\hline Isolate 9 & $14.00 \times 10^{3}$ & $2.50 \times 10^{3}$ & $4.00 \times 10^{3}$ & $8.50 \times 10^{3}$ & $13.00 \times 10^{3}$ & $8.20 \times 10^{3}$ & $8.37 \times 10^{3}$ \\
\hline Isolate 10 & $13.50 \times 10^{3}$ & $2.00 \times 10^{3}$ & $3.50 \times 10^{3}$ & $9.00 \times 10^{3}$ & $11.50 \times 10^{3}$ & $8.50 \times 10^{3}$ & $8.00 \times 10^{3}$ \\
\hline Isolate 11 & $10.00 \times 10^{3}$ & $1.50 \times 10^{3}$ & $4.00 \times 10^{3}$ & $8.00 \times 10^{3}$ & $13.45 \times 10^{3}$ & $7.50 \times 10^{3}$ & $7.42 \times 10^{3}$ \\
\hline Isolate $12 *$ & $15.00 \times 10^{3}$ & $2.00 \times 10^{3}$ & $3.20 \times 10^{3}$ & $9.00 \times 10^{3}$ & $13.20 \times 10^{3}$ & $8.00 \times 10^{3}$ & $8.40 \times 10^{3}$ \\
\hline Isolate $13 *$ & $16.20 \times 10^{3}$ & $2.00 \times 10^{3}$ & $4.50 \times 10^{3}$ & $8.50 \times 10^{3}$ & $11.00 \times 10^{3}$ & $7.00 \times 10^{3}$ & $8.20 \times 10^{3}$ \\
\hline Isolate $14 *$ & $14.50 \times 10^{3}$ & $1.50 \times 10^{3}$ & $4.20 \times 10^{3}$ & $9.20 \times 10^{3}$ & $12.20 \times 10^{3}$ & $8.00 \times 10^{3}$ & $8.27 \times 10^{3}$ \\
\hline Isolate $15^{*}$ & $12.00 \times 10^{3}$ & $1.50 \times 10^{3}$ & $2.50 \times 10^{3}$ & $8.20 \times 10^{3}$ & $13.40 \times 10^{3}$ & $7.50 \times 10^{3}$ & $7.53 \times 10^{3}$ \\
\hline Isolate $16^{*}$ & $10.00 \times 10^{3}$ & $2.20 \times 10^{3}$ & $2.50 \times 10^{3}$ & $8.50 \times 10^{3}$ & $13.00 \times 10^{3}$ & $7.00 \times 10^{3}$ & $6.64 \times 10^{3}$ \\
\hline Mean & $15.21 \times 10^{3}$ & $2.41 \times 10^{3}$ & $5.49 \times 10^{3}$ & $9.78 \times 10^{3}$ & $12.65 \times 10^{3}$ & $7.87 \times 10^{3}$ & $8.55 \times 10^{3}$ \\
\hline
\end{tabular}

*Isolates from hosts other than apple

Plate.1 Cultural characteristics of different isolates of Alternaria alternata f. sp. mali (1-11) and Alternaria alternata (12-16) on PDA medium
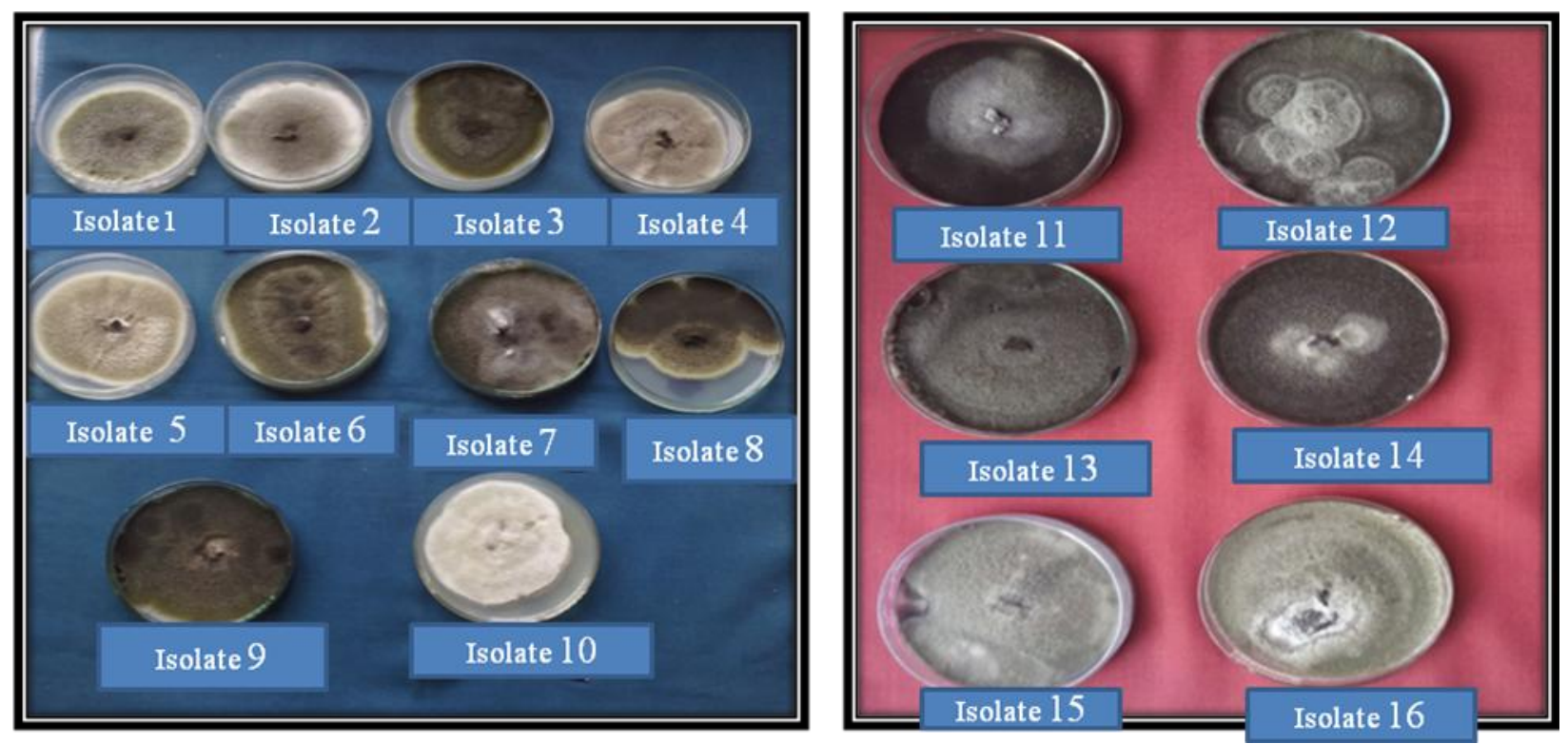
Isolates studied also varied in colony colours (Plate 1, Table 3). Dark olivaceous green colonies were observed in two isolates viz. I11, I-12. Four isolates viz. I-2,I-4,I-7,I-10,I-14 were olivaceous, one isolate I-1 was dark olivaceous but with dark centre, two isolates viz. I-2, I-9, I-13, I-15 were olivaceous green and two isolates viz. I-3, I-5 were light olive green. I-6 was olivaceous with grayish surface and brownish centre. The colony margins varied from regular to irregular (Plate 1). Regular margins were observed in eight isolates viz. I-1, I-3, I-4, I-5, I-8, I-14, I-15, I16. Three isolates (I-6, I-7, I-11) had irregular margins and remaining five (I-2, I-9, I-10, I12, I-13) were with slightly irregular margins. In some cases margins were followed by white or grey rim.

All the isolates impregnated the media with a colour mostly grey to brown with some variations which were clearly visible from the underside of plates (Table 3). Two isolates (I2, I-6) imparted dark grey colour with light grey margin, three isolates (I-5,I-8,I-10) were brown with light grey margin and four (I-1,I3, I-11, I-15) were smoky grey. Two isolates (I-7, I-9) were light grey with brown centre and two (I-13 and I-16) were light grey with dark grey centre. One isolate (I-4) produced grey with light grey margin and I-12 was light brown with light grey margin, while the colour produced by I-14 was greyish with light grey margin and brown centre.

The results of present investigation are in accordance with Sood (1998) who also reported maximum growth of Alternaria alternata causing post-harvest rot of tomato on potato dextrose agar medium followed by Richard's medium. Singh et al., (2001) reported that potato dextrose agar medium supported better mycelial growth and sporulation of Alternaria alternata followed by Richard's medium, Czapek's dox agar media and Asthana medium. In similar studies little variation in conidial colour of Alternaria panax was observed by Quayyum et al., (2005). The results are in agreement with Sofi et al., (2013) who found that the colony color of $A$. mali isolated from apple was light to dark olivaceous with greenish or brownish tinge. In case of $A$. alternata isolated from ribben plants colony colour black to olivaceous black or grayish colour on PDA medium was found (Muthukumar and Venkatesh, 2013). Thirty two isolates of $A$ brassicicola for colony color and radial growth were observed by (Deep et al., 2014). Colony colour of $A$. brassicicola varied from olive green to dark olivaceous black on PDA. The isolates colony had cottony and velvety texture on PDA medium. The results are in agreement with (Barry et al., 2002) examined 308 isolates of Alternaria spp. colonies generally had a cottony texture on group 4 . Alternaria blotch, causal organism A. mali, colonies varied in their cultural behavior ranging from velvety to cottony (Sofi et al., 2013). Remarkable variation was observed on spore production and sporulation time on different media and temperature.

\section{References}

Barry MP and Themis JM. 2002. Morphological, pathogenic, and molecular characterization of Alternaria isolates associated with Alternaria late blight of Pistachio. Phytopathology 92: 406-416.

Deep S, Sharma P, Bahera N and Chowdappa P. 2014. Diversity in Indian isolates of Alternaria brassisicola (Schwein) Wiltshire causing black leaf spot disease in cauliflower. Plant Pathology Journal 13: 232-245.

Filajdic N and Sutton TB. 1991. Identification and distribution of Alternaria mali on apples in North Carolina and susceptibility of different varieties of 
apple to Alternaria blotch. Plant Disease 75: 1045-1048.

Jones AI and Aldwinkle HS. 1990. Compendium of apple and pear disease. American Phytopathological Society, St. Paul, Minnesota, APS Press. 100 p.

Muthukumar A and Venkatesh A. 2013. A new record of leaf blight of ribben plant caused by Alternaria alternata in India. Journal on New Biological Reports 2: 228-230.

Quayyum HA, Dobinson KF and Traquair JA. 2005. Conidial morphology, virulence, molecular characterization and host parasite interactions of selected Alternaria panax isolates on American ginseng. Canadian Journal of Botany 83: 1133-1143.
Singh J and Majumdar VL. 2001. Efficacy of plant extract against Alternaria alternata the incident of fruit rot of pomegranate (Punica granatum L). Journal of Mycology and Plant Pathology 31: 346-349.

Sofi TA, Beig MA, Dar Hassan Gh, Ahangar FA and Hamid A. 2013. Virulence variation in Alternaria mali (Roberts) and evaluation of systemic acquired resistance (SAR) activators for the management of Alternaria leaf blotch of apple. Emirates Journal of Food and Agriculture 25: 196-204.

Sood R. 1998. Studies on post-harvest rot of tomato caused by Alternaria spp. M.Sc. Thesis. Dr. Y.S. Parmar University of Horticulture and Forestry, Nauni, Solan, $65 \mathrm{p}$.

\section{How to cite this article:}

Praneet Chauhan, A.K. Gupta, J.N. Sharma, Monica Sharma, J.S. Chandel and Gupta, R.K. 2018. Cultural Characterization of Alternaria spp. Associated with Alternaria Blotch of Apple. Int.J.Curr.Microbiol.App.Sci. 7(08): 1766-1773. doi: https://doi.org/10.20546/ijcmas.2018.708.202 